\title{
Strategies speakers use to achieve a good communication
}

\author{
VANDA LUCIA ZaMmUner \\ Universidad de Padua (Italia)
}

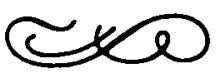

\section{Resumen}

Este informe presenta el análisis de cuatro discursos - producidos por dos bablantes en dos situaciones grupales distintas - en términos de estrategias discursivas denominadas Maniobras Cognitivas (Zammuner, 1981). Tal análisis se propone definir basta qué punto y en qué forma organizan los bablantes sus discursos para lograr ciertas metas comunicacionales. Los discursos fueron producidos en dos contextos que diferian en el tipo de audiencia, nivel de formalismo, grado en que los participantes se cono. cian y compartian sus metas y grado de conocimiento relevante compartido. Los resultados mostraron que los hablantes utilizaron, en diferente grado según el contexto, estrategias tales como especificaciones, repeticiones, paráfrasis, ataques, disgresiones, condicionales y enfatizaciones. Sin embargo, el uso de otras estrategias y su localización en el discurso fue muy similar en ambos contextos (por ej., la explicitación de premisas) y ciertas estrategias guardaban relación con las babilidades y preferencias individuales. El método y los resultados son considerados con respecto a la planificación estratégica del discurso y la interacción social.

Palabras clave: análisis del discurso, comunicación.

\section{Abstract}

This paper reports the analysis of four talks - produced by two speakers in two different group situations- in terms of a set of discourse strategies called Cognitive Manoeuvnes (Zammuner, 1981). The analysis aims at defining, in given social and linguistic contexts, to what extent and how speakers organize their talks to achieve certain communicative goals. The talks were produced in two contexts which differed in terms of audience type, level of formality, extent to which participants knew each other and shared goals, as well as in terms of amount of relevant shared knowledge. Results showed that speakers used, to a different degree in the two contexts, such strategies as specifications, repeats, rephrasing, attacks, branching out, stating something conditionally and stressing. However, the use of certain strategies, and their placement within the discourse, were fairly common across contexts -e.g., the explicitation of premises - while for others it was related to individual idiosyncratic preference and ability. The analysis method and the obtained results are presented in relation to the interaction between strategic planning of discouse and social interaction.

Keywords: discourse analysis, communication

Dirección del autor: Dipartimento di Psicologia dello Sviluppo e della Socializzazione, Universitá degli Studi di Padova, Via Beato Pellegrino 26, 35137 Padova.

Original recibido: junio 1989. 


\section{8}

\section{INTRODUCCION: STRATEGIC PLANNING}

Social interactions are rule- governed. Their occurrence is the result of the interplay of (and may be analysed with respect to) different factors and dimensions which are locally relevant ${ }^{1}$. At a general level, these pertain to different aspects of life, about which individuals have cognitive representations, which are activated, whenever necessary, to guide the execution of actions or their interpretation. These are organized as knowledge structures - or schematawhich in turn may embed other schemata or structures. For instance, people have social knowledge schemata pertaining to different and common social experiences (e.g., going to the theatre or the restaurant; for an extensive discussion, see Arcuri, 1985), as well as linguistic schemata (e.g., those defining what a narrative is and its structure).

Social interactions are complex actions whose execution, apart from the activation of social knowledge structures, requires participants to use «conversational» knowledge to actualize their goals by means of the main available device, i.e., language. Conversational knowledge, however, is a cover term for different knowledge structures pertaining to different domains - syntactic, semantic, pragmatic, stylistic, rhetoric, textual and socio-cultural, activated both in comprehension and production. Because producing a discourse is such a complex task, a strategic approach is necessary to guarantee a fast economic task execution within the usual time and resources (memory and processing) limitations. The recourse in comprehension to strategies of different kinds, and at different hierarchical levels, is discussed extensively by van Dijk an Kintsch (1983).

The notion of strategy is used to describe and explain the production of a whole range of human actions, such as learning something, solving a problem, or trying to overcome and/or control negative emotional reactions. As regards linguistic interactions, researchers have defined and analysed logical and affective strategies (Burgoon \& Bettinghaus, 1980); strategies people use to comply with politeness requirements (Cacciari, 1985), acquire knowledge in order to reduce interpersonal uncertainty (Berger \& Bradac, 1982), or persuade others and enhance adaptation (Clark, Willinghanz and O'Dell, 1983); and so forth. Though there is no explicit reference to it, other available studies of discourse production nonetheless seem to involve the idea of strategic choice (e.g., Clark $\&$ Murphy, 1982). In sum, recent research shows both theoretical interest and empirical support for the idea of strategy use, although the very notion of strategy is rarely defined and discussed explicitly (see van Dijk \& Kintsch, 1983; Zammuner, 1981, 1985, 1987a, b, c):

At a general level, a straegy may be seen as the cognitive representation of the (subjective) optimal way to reach a certain goal. In a linguistic production, strategies are formed and/or activated both locally and globally, i.e., at different hierarchical planning levels. Because of the variety of knowledge domains which are relevant in a linguistic interaction, strategies will rely on knowledge pertaining to each of these. There will be social, pragmatic, syntactic, semantic and textual strategies, all contributing in the end, but often to a different extent and in relation to different aspects, to the organization and structure of the product, i.e., the discourse. The term «cognitive» refers to the knowledge representations which pertain to these domains. These representations interact with each other in different ways and at different levels to allow for coherent discourse, 
both with respect to itself and with respect to its context of production (see van Dijk an Kintsch, 1983; Zammuner, 1985, 1986, 1987a, b, c).

The general theoretical framework here adopted can be briefly summarised as follows. A main problem-solving activity for a speaker at the short-term planning level is related to the discourse organization and structure. We may assume that the global discourse content and structure are defined on the basis of higher level goals a speaker has in relation to relevant aspects of the production context. These goals, usually, are not expressed directly in the produced discourse, although they certainly contribute to defining some aspects of the production. This long-term planning level, based on the activation of the earlier mentioned knowledge domains, does not define how the «selected» propositions are going to be expressed linguistically, nor their sequential order, which relations should be assigned to a set of them, or their specific syntactic realization (see Zammuner, 1981, 1987b-c, 1987f, for a more detailed discussion). These decisions fall under the short-term planning level and are due to the activation of strategies such as those here called «Cognitive Manoeuvres».

In order for this level of choice to be congruent with a speaker's goals for a specific linguistic interaction, the activated strategies depend on the higher planning level. However, they may in turn give input to that level if changes in planning become necessary as the interaction/discourse develops. In sum, cognitive manoeuvres are activated coherently with the higher planning level and work on pre-defined propositional content which, in principle, does not include the higher macro-propositions. In other words, these strategies are used to define the bow of a communication and are applied to a predefined what. However, decisions related to the what and how might interact under certain conditions, or choices and constraints related to the bow might have an effect on the what.

The general hypothesis of this research was that the analysis of the choices made by a speaker at this short-term planning level allows us to try and understand how contextually relevant variables are taken into account in the organization of the discourse (to be) produced (see also Zammuner, 1987d, e; Zammuner and Boscolo, 1987).

\section{THE RESEARCH: THE CONTEXTUAL RELEVANCE OF STRATEGIC CHOICES}

CONTEXT OF PRODUCTION. The discourses to be analyzed were produce by two women, Delia and Lucia, in two different group situations:

1. A series of meetings among women nurses who discussed several problems related to their job as hospital workers and their specific situation as women workers. Out of these meetings grew the decision to organize a public debate for all women workers of that hospital ${ }^{2}$.

2. The public debate which resulted from the decisions taken at the meetings just mentioned.

Context 1, the «Closed Debates», was characterized by (i) a high level of informality, in that all participants knew each other rather well and the explicit purpose of the meeting was to freely discuss problems that seemed relevant, in order to see what «practical» action could be taken to improve women workers' condition within their work place, etc. (ii) 
The participants had a cooperative attitude toward each other's ideas and proposals, because they knew they all shared a common political perspective (i.e., leftist and feminist) and had a similar ideological and experiential background. (iii) There were differences in the occupational an educational status of participants (e.g., ranging from highest (surgeon) to lowest (simple nurse or switchboard operator), but, because of ii, these, as well as age or other variables, were thought not to be of importance.

Context 2, the Open Debate, was characterized in terms of i-iii above but only to some extent. In this meeting, not all participants knew each other well, nor could they all be thought to share the feminist ideological perspective which was central to the debate itself or be in favor of the action which would be advocated in the end -the constitution of a women - only action group which would be a counterpart to the already existing trade-union group. Because this meeting was attended by the group of women who had organized it (G1) and by roughgly 20 other women (G2) who had seen a leaflet calling the meeting, the total group was not altogether homogeneous. However, G2 could be assumed to have at least some interest in the ideas and proposals of G1. The goals of G1 and G2 differed. G2's goal was to get to know the (ideological and action) orientation of G1. G1's main goal was to try an get G2 involved in their action proposal. Because of the difference between G1's and G2's goals, their expectations and amount of shared knowledge, context 2 required a higher level of discourse monotoring than context 1 . The assumption here was that goals, expectations and knowledge assumed by speakers as shared form the basis from which the information expressed in a discourse starts from an develops.

DISCOURSE ANALYSIS. The talks were all argumentative in nature and, although produced in a group situation, they resemble lengthy monologues. In fact, for the open debate, the two discourses which will be analyzed were those opening the debate itself, with Delia bẹing the introductory speaker.

The linguistic productions were tape-recorded in both contexts with the consent of all participants. They were carefully transcribed, taking into account silent and filled pauses, hesitations, false starts and intonation contours. Notes were made of speakers' orientation, non-verbal behaviour and other relevant aspects of the communicative setting. The length of each analysed talk, in terms of spoken time, number of sentences and total number of words produced, has been quite different. However, the results are comparable, using percentage data with respect to each production ${ }^{3}$.

The analysis was carried out in terms of a set of strategies called Cognitive Manoeuvres. These fall into the following five types: Setting, Introducing, Elaborating, Focussing and Diverting (see table 1; they are described and discussed in detail in Zammuner, 1981). In order to see a text part as being due to the activation of a certain strategy, various kinds of information need to be considered syntactic, prosodic, semantic, textual, pragmatic and social aspects relevant for and/or inherent in the discourse. The hypothesis is that they were activated by the speaker in producing her discourse on the basis of various knowledge structures. Any given meaningful text part - from the very small (word, clause) to 
larger discourse segments - may be due to the concommitant activation of several strategies, whose scope may also vary. Each strategy represents the «solution" for a more or less local communicative and/or informational "problem» in relation to a relevant aspect of the production context the speaker took into consideration. As we would expect, the actual semantic structure of argumentative discourses is quite complex and may be characterized in terms of higher and lower level «nodes». Each «node» specifies what relation a given discourse part has with preceding and/or following discourse parts, as well as with a speaker's goals and the production context. It should be noted that almost all discourse elements, at the superficial level - from choice of words and syntactic frames to intonation- express some aspects of the strategic planning adopted (see van Dijk and Kintsch, 1983; Zammuner, 1981, 1987b, c).

\section{TABLE 1}

(Percentage frequencies are computed for each speaker with respect to total amount of CM produced by each speaker)

\begin{tabular}{ccclll}
\hline \multicolumn{2}{c}{ CLOSED } & \multicolumn{2}{c}{ OPEN } & \multicolumn{2}{l}{ CONTEXTS } \\
DELIA LUCIA & DELIA & LUCIA & SPEAKERS & \\
\hline \multicolumn{7}{c}{ \% COGNITIVE MANOEUVRES } & & TYPE \\
\hline 3.2 & 6.1 & 3.5 & 7.9 & Give a premise & Seeting \\
4.1 & 4.9 & 7.9 & 4.4 & Enlarge/Elaborate & Elaborating \\
2.2 & 4.3 & 2.0 & 0.4 & Go toward greater specificity & Elaborating \\
5.7 & 4.9 & 0.9 & 0.9 & Repeat/Rephrase (+/- stress) & Focussing \\
8.9 & 13.9 & 3.5 & 2.5 & Specify & Focussing \\
14.2 & 7.6 & 4.0 & 11.4 & Stress/Emphasize . & Focussing \\
0.9 & 3.5 & 2.0 & 0.0. & Distinguish between 2 ideas & Focussing \\
0.9 & 4.9 & 3.5 & 0.9 & State conditionally & Focussing \\
5.7 & 2.0 & 0.9 & 1.5 & Branch out & Diverting \\
3.5 & 2.9 & 9.9 & 8.4 & Attack/Criticize & Diverting \\
5.4 & 3.5 & 2.0 & 4.4 & Initiate discontinuities & Diverting \\
316 & 488 & 202 & 202 & Total Number of Cognitive Ma- & \\
& & & & noeuvres & \\
2580 & 3152 & 983 & 733 & Total Number of Words & \\
\hline
\end{tabular}

\section{STRATEGIES SPEAKERS USE}

GENERAL FEATURES. The analysis of the four productions has shown that in the closed context while Delia talked for 43 minutes producing 316 Cognitive Manoeuvres (CM), Lucia talked for 53 minutes, producing $488 \mathrm{CM}$, expressed respectively by 2580 and 3152 words. In C2, on the other hand, Delia produce the same amount of strategies Lucia did, i.e. 202, expressed respectively by 983 and 733 words (see table 1).

These results show quite clearly that each speaker has her own «style», which is fairly independent of context of production. The average number of words which expresses one strategy is always higher for Delia (8.16 words per strategy 
in $\mathrm{C} 1$ and 4.86 in $\mathrm{C} 2$ ) in comparison to Lucia (6.45 in $\mathrm{C} 1$ and 3.63 in $\mathrm{C} 2$ ). In other words, we could say that Delia is a more redundant speaker than Lucia. These same results, however, also show that the specific context of production is related to how tightly structured and «dense» a discourse is in semantic terms. In fact, both speakers produce fewer strategies in C1, that is, in the friendly, relaxed context in which there is no strong need to control the produced discourse in terms of how much redundant or «simplified» it may be and/or appear to the group.

SIMILARITIES ACROSS CONTEXTS. The frequency with which different strategies have been produced by each speaker, in relation to each speaker's total use of CM, allows us to see whether there are (i) idiosyncratic preferences and (ii) choices presumably related to the context of production.

In fig. 1 (and table 1), the percentage frequency of some of the most frequent $\mathrm{CM}$ has been plotted for each speaker in the two contexts. Speakers did use other strategies. However, the low frequency of these $\mathrm{CM}$ - not reported in Table 1- either in both contexts or for both speakers, did not allow any reasonable interpretation of their use. Therefore, they will not be considered in this discussion.

Certain strategies have been used by both speakers more frequently in one context only. Both speakers, in the closed (C1) context, have more often produced a specification strategy with respect to a previously stated idea, sas in the following ${ }^{4}$ excerpt 1 :

1. «(...) (e... sono quattro-cinque mesi che ormai ci troviamo/abbastanza continutivamente)/comunque una volta la settimana... (...)» «(...) (and... we have been meeting already for four/ five months/ rather regularly)/ at least once a week...(...)»

Both speakers have rephrased or repeated an assertion already made, either adding stress to it or making it less important:

2. «(...) (e poi/ proprio... di solito/ le donne non sono abituate a... ritrovarsi...a parlare...cioè...a ritrovarsi al di fuori/ no?/ di quelli che sono gli schemi...) cioè...è abbastanza difficile/ riuscire a trovare 'sti momenti... (...)»

«(...) (and then/ really...women are not usually accustomed... to meet with each other... to talk with each other... taht is... to get outside the usual schemata...) that it...il's difficult/ to be able to find the time for this... (...)»

and they have more often used a branching -out strategy (this strategy would include the «three- part list» proposed by Atkinson (1982), used in persuasive political discourses. See also the discourse fragment reported in brackets in excerpt 2 above): 
TABLE 2

Frequency of use of Cognitive Manoeuvres

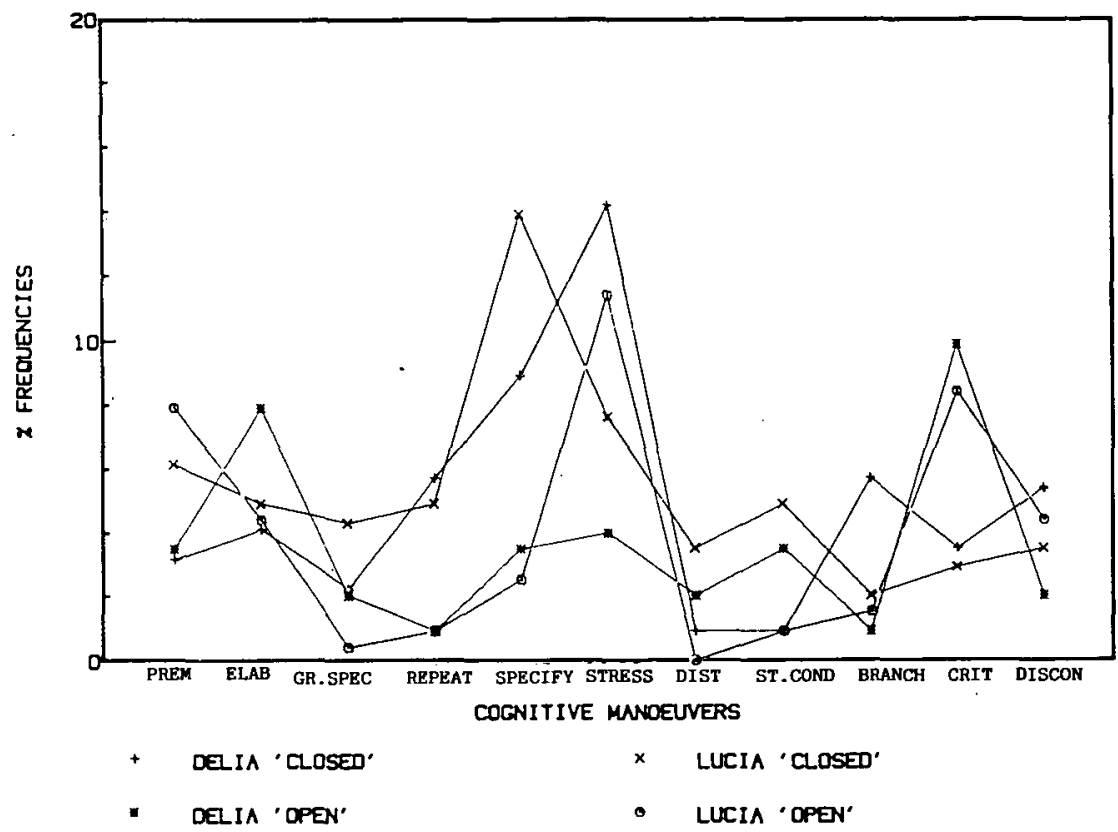

3. «(...) (abbiamo fatto quel...quello schema lì di discussione/ no?/ da fare chiaramente insieme...) cioè/ non c'è nessuno che è brava/ meno brava/che è preparata/che è meno preparata/ che parla meglio/ che parla peggio... (tutte quante insieme/ io direi...vediamo un attimo tutti quelli che sono i problemi - e... ognuna dice...rispetto al problema...hm...su cui si discute/ dice quello che pensa(...)» «(...) (we have prepared this... this discussion schema/ discussion which we will do altogether...) that is/there is no woman that is good/ less good/ that is more prepared/less prepared/that talks better/ that talks worse... (we will discuss together/ I would say... the problems... and each of us will say... her opinion) (...)»

The more frequent use of these strategies seems to be relaxed to the relaxed atmosphere of the group discussion in the closed meetings which did not require a high level of monitoring. Another indication that the discourses were less controlled comes also from the frequent switches from italian to the local dialect that ocurred in these talks, and from the use of many slang words, unfinished phrases, etcetera.

Both speakers, on the other hand, have more often criticised or attacked ideas in the same closed context:

4. «(...) (un'altra cosa appunto che la Sandra riportava/ è che durante...lei ha fatto anche lei dei periodi...di distacco sindacale/ no?/ e diceva/ no?/) diceva che le donne che si presentavano/ chiaramente avevano con lei un rapporto/ diverso che non con i maschi... (...)»

«(...) (another thing that Sandra told us/ is that during ...she has also 
worked as trade-unionist) and $\mathrm{X}$ was saying / that all the women who went there ( = trade-union office)/ clearly had with her a different relationship/ than they had with male trade-unionists...(...)»

The greater reliance within this context on shared knowledge and goals, therefore, had as an effect that speakers did not have to explicitly verbalize their disagreement with certain ideological perspectives which were in constrast with their own and which were instead discussed in the open context (e.g., the problem of women's housework and how society sees women's family role).

DIFFERENCES ACROSS CONTEXTS: DELIA. As regards the remaining $C M$ that were activated with some frequency, the differential use of individual strategies seemed to be more related to each speaker's own idiosyncratic preferences or to her specific role in each context.

Delia, in both contexts, has used, with the same proportional frequency, the strategies of giving an explicit premise for te preceding or following discourse (exe. 5) and of going toward greater specificity with respect to a previously mentioned idea (as in exc. 6, which reports only the beginning discourse part to which this strategy applies).

5. «(...) (il discorso era anche come...) che nel pubblico impiego le donne hanno tutti i lavori abbastanza dequalificati (...)»

«(...) (what we discussed also was related to...) the fact that in the public employement sector women have de-qualified jobs (...)»

6. «(...) rispetto al lavoro esterno/ chiaramente abbiamo l'analisi di quella che è la nostra condizione di donne ospedaliere... qui chiaramente abbiamo fatto tutti i discorsi come... (...)»

«(...) as regards women's external work (their job)/ clearly we have analysed our own condition as hospital workers...here...clearly we have discussed all the issues like...(...)»

In the open context, where Delia had the very important role of being the introductory speaker to a debate that, it was hoped, would result in establishment of a series of meetings and in concrete actions, she has elaborated a previously mentioned notion more frequently than in the closed context (exc. 7) and she has, much more often, stated her opinions conditionally (exc. 8).

7. «(...) (le donne/ anche nel lavoro esterno/ di solito continuano ad essere subalterne rispetto a tutti gli uomini/ no?/) cioè/ siamo sempre le meno qualificate/ siamo sempre quelle che hanno i lavori...cosi...con le qualifiche più basse...a salari più bassi...con condizioni peggiori (...)»

«(...) (women, also in their jobs, remain in a subordinate position with respect to men)/ that is/ we are always the least qualified workers... we always have the lowest wages... and the worst (working) conditions (...)»

8. «(...) (cioè/ questi sono i discorsi da cui siamo partite...) credo che siano i discorsi...così...per cui siamo tutte qui stasera/ no?/ (...)» «(...) (these were the ideas from wchic we started)/ I think that these are the discourses (reasons)... well... for which we are all here tonight (...)»

She has also more often used the strategy of making a distinction within one notion, or between two notions or two aspects of one notion:

9. «(...) (andare a vedere la donna in questo tipo di società che tipo di ruolo vive...) cioè che tipo di funzioni/ no?/ che le vengono date... che sono 
quelle/ dentro la famiglia/ di essere moglie e madre... (...)" «(...) (to see which role women have in this society...) that is, what type o functions are assigned to her... and these are/ within the family/ those of being a wife and a mother... (...)》

These strategies seem to be related to her goal as a main speaker to avoid ambiguities by making as explicit as possible the conceptual reality dealt with, in order to enhance the audience's understanding, and therefore, its acceptance of the proposed orientations and actions.

In the closed context, on the other hand, she used stress (i.e., assigning differential relevance, to a certain idea or to an aspect of it) much more often than in the open context (see examples 10 and 11), i.e. 14.2 vs. $4.0 \%$. It should be noted that differential relevance may be expressed, not only by intonational stress, but also by a certain lexical choice, by sintactic constructions, or by other means such as repetitions. She also introduced semantic discontinuities to a greater extent (see excerpt 12).

10. «(..) nel commercio le donne sono tutte impiegate (...)» «(..) in the business sector women are all clerks (...)»

11. «(..) questa è una struttura gerarchica che viene sempre riprodotta (...)» «(...) this however is a hierarchical structure that is always applied (...)»

12. «(...) (le donne hanno sempre dei lavori dequalificati) però questa non è che... particolarmente nell'ospedale... nel comune... o in altri posti... (questa è proprio... una... realtà che la donna vive sempre nel lavoro esterno...) (...)»

«(...) (women always have rather de-qualified positions) but this isn't a situation that... is true at the hospital only...at the municipality... or in other places... (this is indeed... a... reality which women always face in their jobs...) (...)"

Stress assigns to a discourse part a strength which Delia seems to prefer avoiding in the public debate, perhaps with the aim of not giving a «bad» impression, i.e. that she - and the entire group which called the debate- would talk like politicians (i.e. being demagogic) or with a male style (i.e. too aggressive). The introduction of discontinuities, on the other hand, useful in setting an «anchor» position from which the following discourse develops, structures the discourse in terms of antithetical positions. Therefore, although the latter strategy enables a speaker to direct the focus of attention of his/her audience (see Zammuner, 1982, 1984, 1987d, e), it stresses locally or globally relevant contrapositions and differences in ideas or orientation Delia avoided using this strategy often in the more problematic open context.

LUCIA. A main speaker for G1, and usually a very effective and eloquent one, this speaker differed in her role from Delia, in that, in the open debate, she had to support and integrate, if necessary, Delia's introductory discourse. However, this role was not defined in terms of explicitly stated rules. Her talk, that is, the things she said in her discourse, as well as the specific points at which she did talk, showed hat she was very attentive to her role requirements.

In both contexts Lucia used, with roughly the same frequency, the strategies of giving a premise and initiating a discontinuity (although she did so slightly more frequently in the open context) and elaborating a discourse part. In the open debate, apart from those stategies, which were mentioned already for both speakers, she increased very much her use of stress $(11.4 \%$, vs $7.6 \%$ in the 
closed context) to underline many of the notions she was expressing. This shows that, to some extent at least, Lucia evaluated differently the situational requirements and thought it appropriate to emphasise the ideas she expressed in order to make them more salient or clearer to G2. It should be noted that in most of her talk she simply expanded on notions already introduced by Delia. Therefore, it seems that, in general, she thought it necessary to assign greater relevance to opinions she felt had not yet been expressed with the necessary strength.

In the closed debate only, on the other hand, she had recourse to the strategies of stating conditionally and making a distinction between two notions or two aspects of a notion. In other words, unlike Delia, Lucia allows herself to express doubts or point to possible problems only in the more «private» setting. In the «public» situation she prefers to verbalize her opinions more forcefully.

\section{DISCUSSION}

The discussed aspects of the strategic control speakers have over the organization of their talks seem to indicate that speakers use, more or less frequently, certain specific strategies according to their evaluation of the requirements of the context in which they talk. So, the «open» debate, which requires a close monitoring of one's own talk in order to avoid misunderstandings of one's own idelogical and pragmatic viewpoints (as well as of G1's goals), results in a more frequent use of strategies whose aim and effect is that of giving greater relevance and clarity to ideas that G1 considers very important. Outsiders's opinions are instead often quoted and strongly criticized. The pragmatic goal here was definitely that of establishing a clear antithesis between the attitudes and opinions of G1 -as a wome's group - ant those of all other trade-unionists.

On the other hand, different speakers evaluate idiosyncratically the requirements and constraints associated with each context. Perhaps, each speaker actually has access to different resources, and personality factors might play an important role here. The effect is that there are idosyncratic changes in the strategic approach used by each speaker in the two situations. Delia only, for instance, elaborated the topics and ideas she discussed in the «open» debate to a greater extent than in the «closed» debates an stated her ideas less forcefully in the former than the latter context, so that the audience could, in fact, consider them as provisional statements or suggestions which could be argued against or negotiated later. She also controlled the emphasis she assigned to her statements by using a more flat intonation, with longer pauses and more frequent hesitations, and so forth.

The topics discussed in both contexts by both speakers did not vary much, nor did the specific ideas which were stated. Both speakers, because of their activity as prominent members of the local trade-union, were accustomed to talking in public to relatively large audiences. Therefore, the similarities an differences between the two speakers and contexts which were singled out support the idea that, while idiosyncratic evaluations and preferences do have an impact on the discourse organization and strategic control, speakers tailor their talks according to their specific role and aims within a specific context, and in relation to their evaluation of context requirements. It should also be noted that the overall strategic organization of the discourse is such taht idiosyncratic preferences -e.g. use of stress, level of information redundancy, etc. - seem 
to be balanced by certain strategic choices- e.g. elaborations, specifications, etc.- which a differente speaker, with different idiosyncrasies, would not be likely to use. As a consequence, it is the interplay between resources which are available to a speaker and their differential exploitation that becomes very important in defining how a speaker will construct and structure his/her discourse. These results, altogether, seem to support the hypothesis that speakers do take into account the requirements of the situation in which they talk to structure and organize their discourse so that it is most effective to achieve their goals.

In sum, the analysis of discourse productions in terms of the set of straytegies called Cognitive Manoeuvres seems to provide a theoretical and empirical framework which is productive in allowing us to define at least some important aspects of the cognitive representation speakers have of the social interaction in which they are actively engaged, and of the strategic processes activated to manage the interaction successfully. In fact, as the present analysis indicates, the interpretation of different discourse aspects in terms of these strategies enables us to start defining what relationship the product -a given communication- has with a speaker's goals in a given context, and with the speaker's evaluation of the salient characteristics of that context.

The talks which were analyzed do not provide sufficient quantitative data which would enable us to draw any general conclusion about the extent to which people speak the way they do because they rely on their characteristic style and/or because they are sensitive to specific aspects of the situation. However, the analysis has shown certain trends which indicate both the effect of a specific context and the presence of idiosyncratic aspects in the way people talk in socially relevant situations. Therefore, although the specific strategies which were singled out as characteristic either of speakers's style or context variables might not necessarily be present, and/or to the same extent, in discourses produced by other speakers in similar contexts, or by the same speakers in different contexts, yet they represent important indices descriptive of people's communicativa competence at a micro-level.

More data of this type will have to be collected and analyzed using this approach in order to make predictions about context effects and idiosyncratic aspects of production, and their interaction. However, this analysis already shows the importance and productivity of an approach which pays attention to such an interaction in trying to explain specific variations in linguistic production. In other words, the reported results confirm the necessity to analyse human action as embedded in a social context whose complex structure may then be matched with complex knowledge structures, and planning activities based on that knowledge. Discourse, needless to say, is one of the most common and relevant human actions. We need to know more about its production. Within this perspective, the notion of strategic management of resources and constraints seems to have a central role. 


\section{Notes}

1. For instance, when meeting an acquaintance in the street and stopping to greet him/her, we are engaging in a social interaction for which we know that several aspects of the reality at large, or of our lives, are irrelevant -e.g. the results of the last local political elections, what particular paper we are writing at the moment, or our appointment the previous day with our dentist. Other aspects or factors may actually be salient for the interaction itself -e.g. certain facts pertaining to the persons we met, how much time we can spend talking without being late for our next appointment, etcetera.

2. The discourses produce in the «closed» debate are extracted from a larger corpus of data which was previously analyzed in a paper by Zammuner and Job (1979) within a different perspective. 3. The number of produced words is the most acceptable baseline because any other paremeter (e.g., number or sentences, number of topics, etc.) could be objected to, in that it would be theoreticall y not clearly definable or subject to different interpretations according to which perspective is used (see also Matarazzo and Wiens, 1972).

4. The discourse parts reported as excerpts are all taken from the discourse of Delia in the «open» debate. In understanding the context of the discourse part expressing a given strategy. Fragments reported between slashes are intonationally distinct or separated by breathing. Three dots in brackets (...) indicate that there were preceding or following discourse parts not reported in the example. Three dots indicate longer pauses. The provided translation - always very difficult for spoken discourse - to some extent alters the original text to enhance degree of understanding of the reported examples.

\section{References}

Arcuri, L., (1985). Conoscenza Sociale e Processi Psicologici. Bologna, Il Mulino.

Atkinson, J.M., (1982). Public speaking and audience response: Some techniques for inviting applause. In J. M. Atkinson and J. Heritage (Eds.), Structures of Social Action: Studies in Conversational Analysis. Cambridge, Cambridge University Press.

Berger, C. R., \& Bradac, J. J. (1982). Language and Social Knowledge. London, E. Arnold.

Burgoon, M., \& Bettinghaus, E. P., (1980). Persuasive message strategies. In M. Roloff and G. R. Miller (Eds.), Persuasion: Nex Directions in Theory and Research. London, Sage Publications.

CACCIARI, C., (1985). Communicative rituals in a doctor-patient setting. Paper presented at the First International Congress of Applied Psycholinguistics, Barcelona, 17-20 June.

Clark, H. H., \& Murphy, G. I., (1982). Audience design in meaning and reference. In J. F. Le Ny and W. Kintsch (Eds.), Language and Comprebension. Amsterdam, North-Holland.

Clark, R.A.; Willinghanz, S., \& O'dell, L., (1983). The relationship of social cognitive abilities to performance in persuasive tasks. Paper presented at the First International Congress of Applied Psycholinguistics, Barcelona, 17-20 June.

V AN DiJK, T. A., \& KINTSCH, W. (1983). Strategies of Discourse Comprebension. New York, Academic Press.

Matarazzo, J. D., \& Wiens, A. N., (1972). The Interview. Chicago, Aldine-Atherton.

Zammuner, V. L., (1987a). Coherence and strategies in discourse. In M. Charolles (Ed.), The Resolution of discourse. Hamburg, Buske Verlag, in press.

(1987b). Strategies in discourse production: Computational models. Paper presented at the workshop Texts and Text Processing, Poitiiers, September 1986. In press.

(1987c). Discourse planning and production: An outline of the process and some variables. Paper presented at the First European Workshop on Language Generation, Abbey de Royaumont, January 1987. In press.

(1987d). For or against? The expression of attitudes in discourse. Text, 7 (4), 411-434. (1987e). Strategies in the expression of attitudes toward abortion. Paper presented at the Table Ronde «Les agencements discursifs et leurs systèmes de représentation, Paris, June 1986. In press.

(1987f). Pragmatic factors and strategies in discourse production. In A. Bertuccelli Papi \& J. Verschueren (Eds), The Pragmatic Perspective. Selected Papers from the 1985 International Pragmatics Conference, pp. 255-276. Amsterdam, J. Benjamins.

(1986). Children's coherence in discourse: A review. In J. S. Petofi (Ed.), Text Connectedness from Psychological Point of View, pp. 24-63. Hamburg, Buske Verlag.

(1985). Strategie cognitive nella produzione del discorso. Report del Dipartimento di Psi- 
cologia dello Sviluppo e della Socializzazione, no. 18, Problemi del linguaggio, pp. 45-76. Università di Padova.

(1984). Le discontinita' semantiche come strategie di definizione dell'ambito testuale e conversazionale Lingua e Stile, 20 (2): 151-172.

(1982). Semantic discontinuities as text production strategies. In A. Flammer \& W. Kintsch (Eds.), Discourse Processing pp. 137-150. Amsterdam, North-Holland.

(1981). Speech Production. Strategies in Discourse Planning. Hamburg, Buske Verlag.

Zammuner V. L., \& Boscolo, P. (1987). Structures adn strategies in children's requests. Paper presented at the 1987 Intemational Pragmatics Conference, Antwerp, August.

Zammuner V. L., \& JoB, R. (1979). Analyzing conversations: The role of Cognitive Manouvres in linguistic planning. The Italian Joumal of Psychology, 6: 81-98. 